\title{
Metrological assessment of micro flow-meters and drug delivery devices in the scope of the "MeDD" EMRP project
}

\author{
F. Ogheard ${ }^{1, a}$, E. Batista ${ }^{2}$, H. Bissig ${ }^{3}$, H.T. Petter ${ }^{4}$, P. Lucas ${ }^{4}$, A.K. Niemann ${ }^{5}$ \\ ${ }^{1}$ Centre Technique des Industries Aérauliques et Thermiques (LNE-CETIAT), 25 Av. des Arts, 69603 Villeurbanne, France \\ ${ }^{2}$ Portuguese Institut for Quality (IPQ), Rua António Gião 2, 2829-513 Caparica, Portugal \\ ${ }^{3}$ Federal Institut of Metrology (METAS), Lindenweg 50, 3003 Bern-Wabern, Switzerland \\ ${ }^{4}$ Van Swinden Laboratorium B.V. (VSL), Thijsseweg 11, P.O. Box 654, NL-2629 JA, Delft, Netherlands \\ ${ }^{5}$ Danish Technological Institute (DTI), Kongsvang Allé 29, 8000 Aarhus C, Denmark
}

\begin{abstract}
Résumé. Aux échelles des micro et nano-débits de liquides, l'étalonnage revêt un caractère critique, notamment pour des applications telles que le dosage volumétrique et l'administration de médicaments. En particulier, pour des médicaments avec une très courte demi-vie (de l'ordre de la minute), ou pour des médicaments qui requièrent une très faible concentration sanguine pour des raisons de toxicité, tels que les médicaments vasoactifs ou anesthésiants, la quantité exacte de volume administré ainsi que la stabilité du débit sont cruciales. Cependant, en 2012, la traçabilité métrologique sur ces gammes de très faibles débits n'était validée en Europe qu'à partir de $16 \mu \mathrm{l} / \mathrm{min}$. Les instituts nationaux de métrologie LNE-CETIAT, DTI, IPQ, METAS et VSL ont développé, dans le cadre du projet européen de recherche en métrologie "HLT07 Metrology for Drug Delivery - MeDD"[1], des méthodes primaires d'étalonnage couvrant une gamme de débits de liquide allant de $10 \mathrm{ml} / \mathrm{min}$ à $10 \mathrm{nl} / \mathrm{min}$. Cet article présente les références développées dans la première partie du projet et leur validation via une inter-comparaison des résultats obtenus avec un débitmètre massique à effet Coriolis et un pousse-seringue. L'influence de plusieurs paramètres physiques tels que la température, la contre-pression, la viscosité et les pulsations du débit a été étudiée. En ce qui concerne les dispositifs de perfusion, plusieurs caractéristiques ont été testées : le délai de démarrage, la stabilité du débit et le temps de réponse à une occlusion, en fonction de la présence d'accessoires tels que des vannes, aiguilles, tubulures, et en fonction de paramètres physiques tels que la température et la viscosité du liquide. Une partie des résultats obtenus est présentée dans cet article.
\end{abstract}

\section{Introduction}

In various studies infusion technology is considered a technology with underestimated risks due to setting and controlling ultra-low flow rates $(<1 \mathrm{ml} / \mathrm{h})$, especially for multi-pump infusion. Moreover, the influence of the drug delivery device characteristics (start-up delay, compliance, flow stability) and the operating conditions (temperature, viscosity) on the outflow concentration are not well understood.

Drug delivery is the process of administering a pharmaceutical compound to achieve a therapeutic effect. Typically, for a proper drug delivery the total delivered volume (or mass) is the most important parameter. However, there are a significant percentage of drugs for which the actual flow rate is very important for a sound patient treatment.

The commercially available drug delivery devices and also some micro flow meters can go down to a flow rate of less than $1 \mathrm{nl} / \mathrm{min}$ with a claimed, but not verified, uncertainty in the order of only a few percent. Typically not all uncertainty sources are taken into account. Furthermore, for drug delivery devices the uncertainty resulting from the interaction with the drug delivery device accessories is not properly understood nor taken into account.

In the framework of the 2011 Health call of the EMRP (European Metrology Research Programme) the National Metrology Institutes (NMI) or Designated Institutes (DI) LNE-CETIAT, DTI, IPQ, METAS and VSL, joined in a 3-year Research Project (JRP) entitled "HLT07 Metrology for Drug Delivery - MeDD" [1]. This project started in June 2012 and ended in June 2015. The aim of this JRP was to provide traceable calibration services for drug delivery systems for flow rates down to $1 \mathrm{nl} / \mathrm{min}$ with a target uncertainty of $0.5 \%$ in order to develop tools that can make drug delivery more reliable, especially for multi-pump infusion and applications with very low flow rates.

The project was divided in 4 different workpackages (WP), namely:

-WP 1 - Development of the world's first traceability chain for liquid flow rates from $150 \mu \mathrm{l} / \mathrm{min}$ to $1 \mathrm{nl} / \mathrm{min}$ with a target uncertainty of $0.5 \%$.

- WP 2 - Metrological assessment of commercially available flow meters. One of the focal points will be the effect of pulsation on meter performance.

\footnotetext{
a Corresponding author : florestan.ogheard@cetiat.fr
} 
-WP 3 - Metrological assessment and characterization of various types of drug delivery devices in combination with various accessories.

- WP 4 - Dissemination of the results through journal, conference and magazine publications, training and a stakeholder group.

The following chapters summarize the results obtained in this workpackages.

\section{Development of primary standards}

The NMI or DI, METAS, LNE-CETIAT, IPQ, DTI and VSL have developed primary standards to cover the flow rate range from at least $1 \mathrm{ml} / \mathrm{min}$ down to $100 \mathrm{nl} / \mathrm{min}$. The general working principal is the same for all gravimetric setups and consists of a flow generation, connections to a device under test and connections to a water collection on top of a precision balance or an analytical balance. This balance reads the mass, which can be combined with timing equipment to calculate the $\Delta \mathrm{m} / \Delta \mathrm{t}$ quotient.

METAS developed a primary standard to cover the flow rate range from $1 \mathrm{ml} / \mathrm{min}$ down to $100 \mathrm{nl} / \mathrm{min}$ with uncertainties in the range from $0.1 \%$ to $0.6 \%$ for steady flow rates and calibration of pulsating flow rates from 1 $\mathrm{ml} / \mathrm{min}$ down to $1 \mu \mathrm{l} / \mathrm{min}$ with measurement uncertainties from $0.2 \%$ to $2.7 \%$ for the instantaneous flow rates.

According to its mission of national reference laboratory, CETIAT (Centre Technique des Industries Aérauliques et Thermiques, Villeurbanne, France) completed the construction and validation of a modern and innovative calibration laboratory based on the gravimetric method, to cover the flow rate range from $10 \mathrm{l} / \mathrm{h}(167 \mathrm{ml} / \mathrm{min})$ to 1 $\mathrm{ml} / \mathrm{h}(17 \mu \mathrm{l} / \mathrm{min})$ with uncertainties from $0.1 \%$ to $0.6 \%$.

IPQ developed a primary standard to cover the flow rate range from $600 \mathrm{ml} / \mathrm{h}(10 \mathrm{ml} / \mathrm{min})$ to $0.12 \mathrm{ml} / \mathrm{h}(2 \mu \mathrm{l} / \mathrm{min})$ with uncertainties from $0.30 \%$ to $2.5 \%$.

At the Danish Technological Institute (DTI), the newly established primary standard covers a flow range from $100 \mathrm{ml} / \mathrm{h}(1.6 \mathrm{ml} / \mathrm{min})$ to $1 \mu \mathrm{l} / \mathrm{h}(17 \mathrm{nl} / \mathrm{min})$ with uncertainties from $0.05 \%$ to $5 \%$. However, the micro flow laboratory at DTI is accredited to a flow rate from $600 \mathrm{ml} / \mathrm{h}(10 \mathrm{ml} / \mathrm{min})$ to $1 \mathrm{ml} / \mathrm{h}(17 \mu \mathrm{l} / \mathrm{min})$ with uncertainties from $0.05 \%$ to $4 \%$.

VSL developed a water flow standard to cover flow rates from $0.25 \mathrm{~g} / \mathrm{h}(4.2 \mu \mathrm{l} / \mathrm{min})$ to $5000 \mathrm{~g} / \mathrm{h}(83.3 \mathrm{ml} / \mathrm{min})$ with uncertainties of $0.05 \%(100-5000 \mathrm{~g} / \mathrm{h} ; 1.6-83$ $\mathrm{ml} / \mathrm{min}), 0.10 \%(5-100 \mathrm{~g} / \mathrm{h} ; 83-1666 \mu \mathrm{l} / \mathrm{min})$ and 0.10 - $0.3 \%(0.25-5 \mathrm{~g} / \mathrm{h} ; 4.2-83.3 \mu \mathrm{l} / \mathrm{min})$.

More details regarding the primary standards of each partner can be found in [2].

The calibration capabilities and the corresponding uncertainties of the primary standards have been validated by means of an inter-comparison organized within the project [3] for the flow rate range from 10 $\mathrm{ml} / \mathrm{min}$ down to $2 \mu \mathrm{l} / \mathrm{min}$, using a syringe pump and a Coriolis mass flow meter. In the intercomparison also a flow meter manufacturer (Bronkhorst High-Tech - BHT), the National Metrology Institute from Finland (MIKES) and the Lübeck University (FH L) participated. The results obtained can be found in Figure 1 and Figure 2 and are all consistent, except for the flowmeter at the largest flow point.

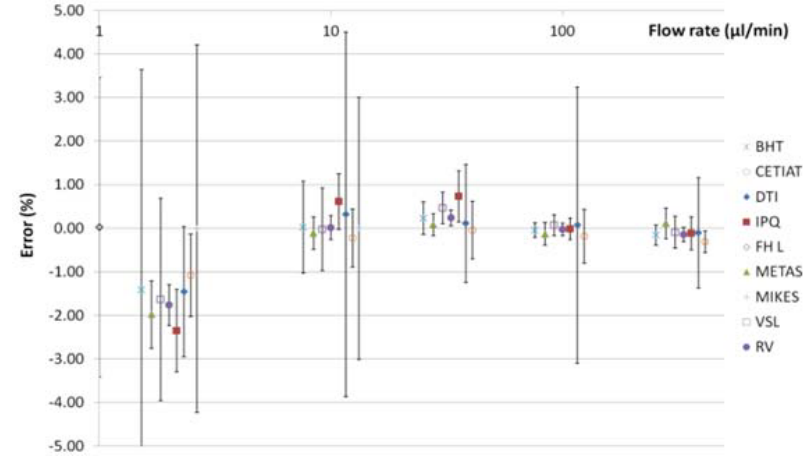

Figure 1. Results of the intercomparison for the syringe pump. The uncertainty includes the uncertainty in reference flow rate, repeatability and the uncertainty due to drift.

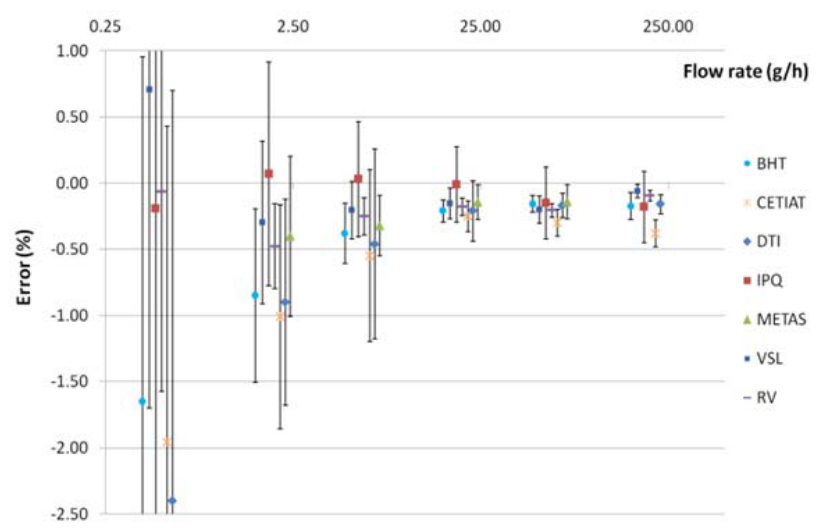

Figure 2. Results of the intercomparison for the flow meter. The uncertainty includes the uncertainty in reference flow rate, repeatability and the uncertainty due to drift.

\section{Flowmeters assessment}

The aim of this task is to determine the influence of various physical parameters and operating conditions on the performance of various types of flow meters. The physical parameters selected are those that are most relevant for drug delivery applications and flow metering: viscosity, back pressure, pulsations and temperature.

The several types of flow meters have been subjected to the tests: a Coriolis mass flow meter from Bronkhorst High-Tech, a Sensirion volumetric thermal flow meter and a pressure drop type flow meter from Alicat Scientific. The results summarized hereafter are fully detailed in [4].

\subsection{Temperature dependency}

The flow meters have been tested at three temperatures of the water flowing through the flow meter and of the air around the flow meter: $10^{\circ} \mathrm{C}, 20^{\circ} \mathrm{C}$, and $30^{\circ} \mathrm{C}$. The mass flow meter and pressure drop flow meter are virtually independent on the temperature. On the other hand, the thermal flow meter accuracy has been found to be dependent on the water temperature. A possible explanation could be the temperature dependence of the 
specific heat capacity of water causing stronger deviations in the non-linear regime of the flow meter.

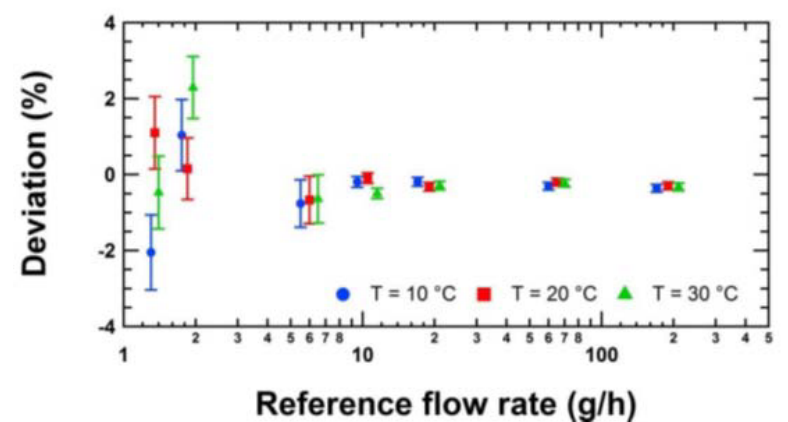

Figure 3. Measured deviations of the Coriolis mass flow meter in the flow rate range from $1.3 \mathrm{~g} / \mathrm{h}$ up to $200 \mathrm{~g} / \mathrm{h}$ at temperatures of $10{ }^{\circ} \mathrm{C}, 20^{\circ} \mathrm{C}$ and $30^{\circ} \mathrm{C}$. The flow rates have been given an artificial off set in order to better visualize the results, for example the last 3 measurements are all for a flow rate of 200 $\mathrm{g} / \mathrm{h}$.

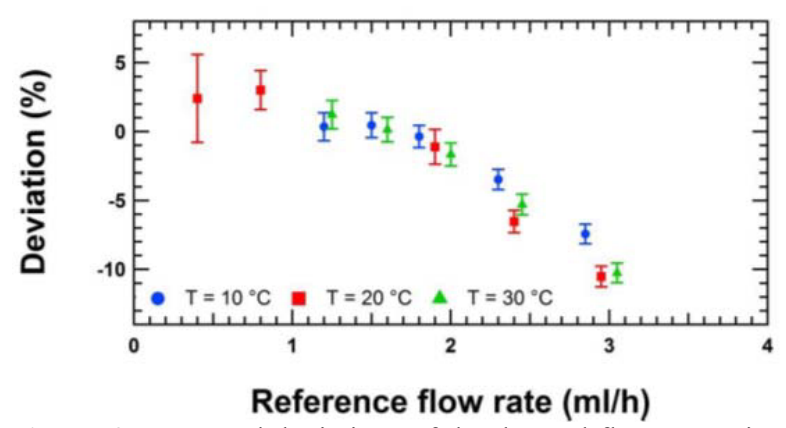

Figure 4. Measured deviations of the thermal flow meter in the flow rate range from $0.4 \mathrm{ml} / \mathrm{h}$ up to $3 \mathrm{ml} / \mathrm{h}$ at temperatures of 10 ${ }^{\circ} \mathrm{C}, 20{ }^{\circ} \mathrm{C}$ and $30{ }^{\circ} \mathrm{C}$. The flow rates have been given an artificial off set in order to better visualize the results, for example the last 3 measurements are all for a flow rate of 3 $\mathrm{ml} / \mathrm{h}$.

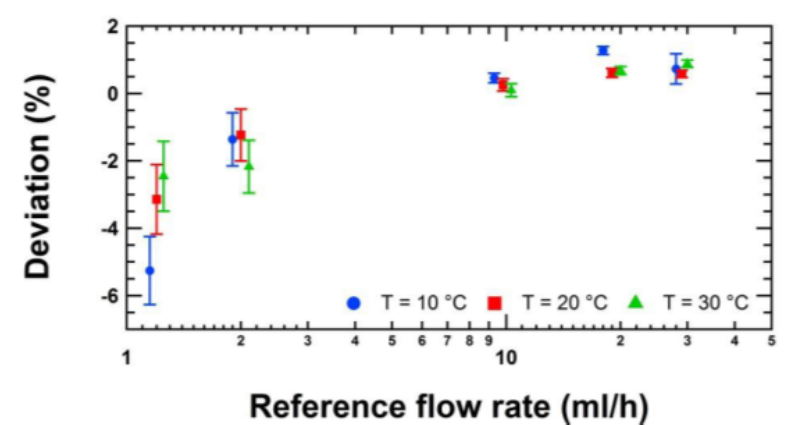

Figure 5. Measured deviations of the pressure drop flow meter in the flow rate range from $1.2 \mathrm{ml} / \mathrm{h}$ up to $30 \mathrm{ml} / \mathrm{h}$ at temperatures of $10{ }^{\circ} \mathrm{C}, 20^{\circ} \mathrm{C}$ and $30^{\circ} \mathrm{C}$. The flow rates have been given an artificial off set in order to better visualize the results, for example the last 3 measurements are all for a flow rate of $30 \mathrm{ml} / \mathrm{h}$.

\subsection{Pulsation dependency}

The three flow meters have been tested using 2 different type of pulsating flow: standard syringe pump (Aladdin) and double syringe pump (Tecan).

The measured deviations of the Coriolis mass flow meter and the thermal flow meter for two different pulsating flows are consistent within the uncertainties. The results of the pressure drop flow meter cannot be used for a conclusion as only one flow generator was used for the measurements.

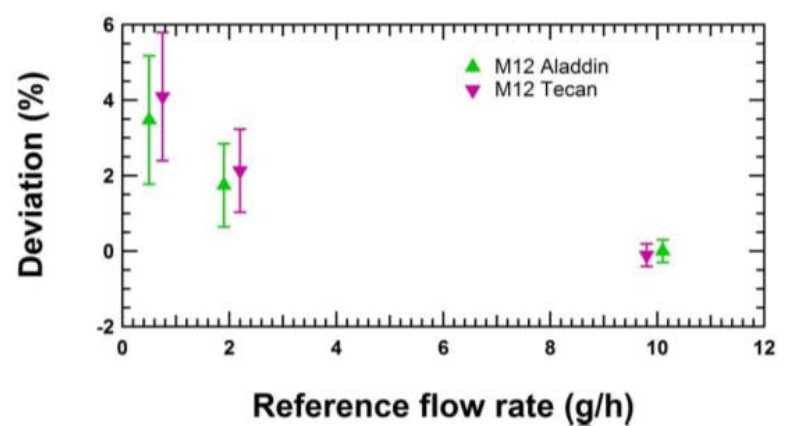

Figure 6. Measured deviations of the Coriolis flow meter in the flow rate range from $0.6 \mathrm{~g} / \mathrm{h}$ up to $10 \mathrm{~g} / \mathrm{h}$ for two different pulsating flows at ambient temperature. The flow rates have been given an artificial off set in order to better visualize the results, for example the last 2 measurements are all for a flow rate of $10 \mathrm{ml} / \mathrm{h}$.

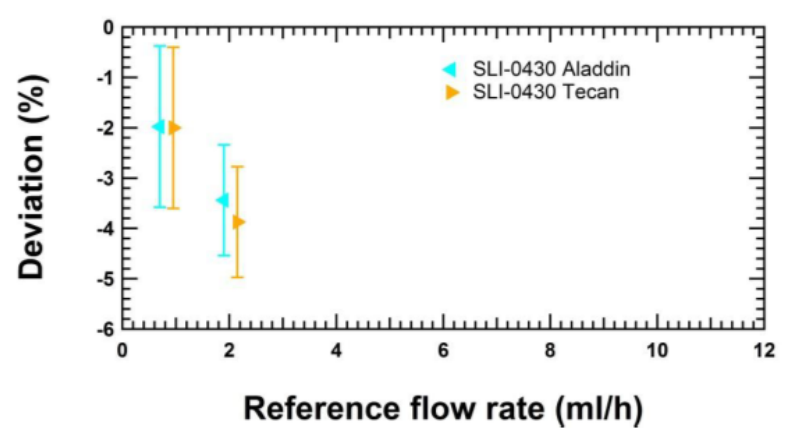

Figure 7. Measured deviations of the thermal flow meter in the flow rate range from $1.0 \mathrm{ml} / \mathrm{h}$ up to $2.0 \mathrm{ml} / \mathrm{h}$ for two different pulsating flows at ambient temperature. The flow rates have been given an artificial off set in order to better visualize the results, for example the last 2 measurements are all for a flow rate of $2 \mathrm{ml} / \mathrm{h}$

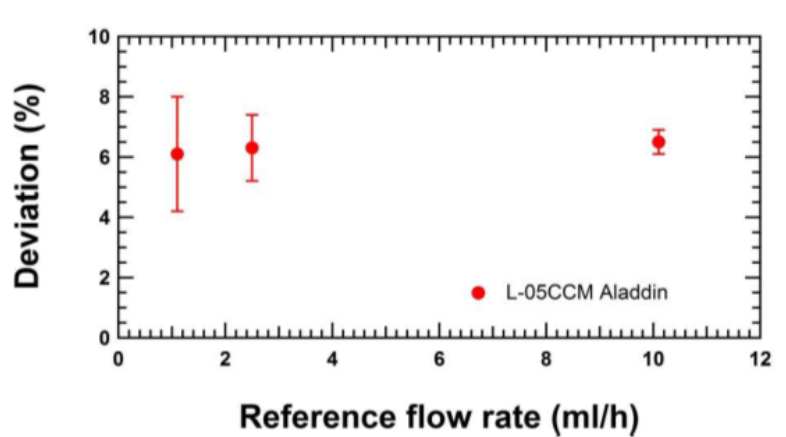

Figure 8. Measured deviations of the pressure drop flow meter in the flow rate range from $0.7 \mathrm{ml} / \mathrm{h}$ up to $11.0 \mathrm{ml} / \mathrm{h}$ for two different pulsating flows at ambient temperature.

\subsection{Back pressure dependency}

The flow meters are tested using 2 different back pressures. The facility already generates a backpressure in the range from $10 \mathrm{mbar}$ to $30 \mathrm{mbar}$ depending on the flow rate. This backpressure corresponds to the order of magnitude of the standard patient back pressure of roughly 17 mbar. Therefore, only one additional back pressure of 170 mbar (10 times patient pressure) is investigated at the following flow rates $0.5 \mathrm{~mL} / \mathrm{h}, 2 \mathrm{~mL} / \mathrm{h}$ 
and $10 \mathrm{~mL} / \mathrm{h}$. The back pressure has been created by a pressure reducing valve installed downstream of the device under test.

As expected, the Coriolis flow meter and the thermal flow meter are not sensitive to any change in back pressure. The pressure drop flow sensor shows at the two lowest flow rates not consistent results for different back pressures. However, the measured deviations at the flow rate of $0.75 \mathrm{ml} / \mathrm{h}$ are still within the stated accuracy of the flow meter.

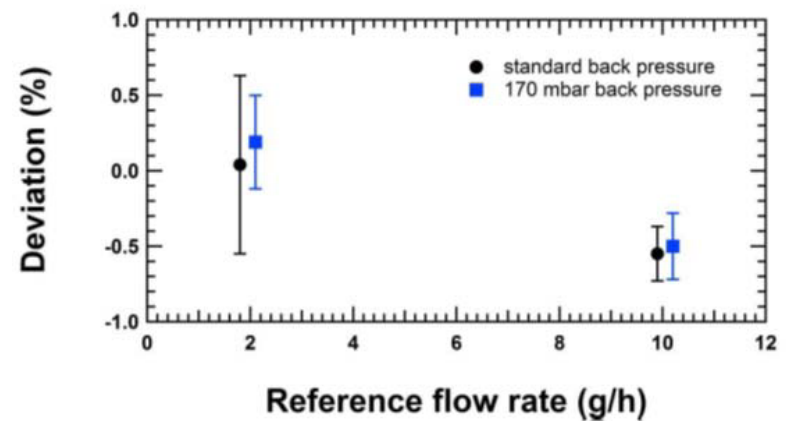

Figure 9. Measured deviations of the Coriolis flow meter in the flow rate range from $2.0 \mathrm{~g} / \mathrm{h}$ up to $10 \mathrm{~g} / \mathrm{h}$ for two different back pressures at a temperature of $22{ }^{\circ} \mathrm{C}$.

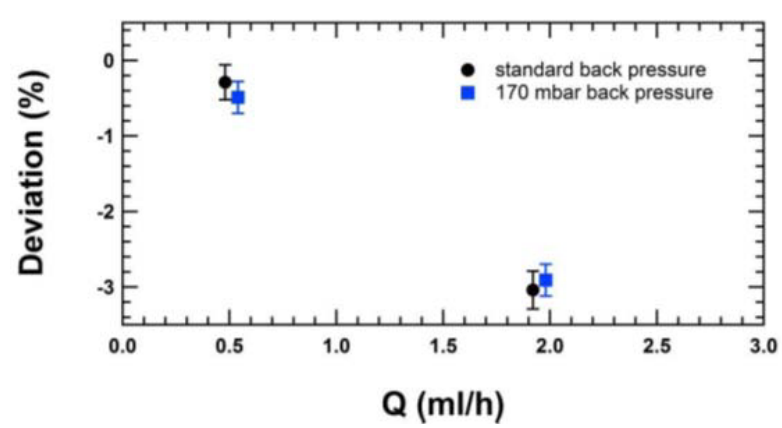

Figure 10. Measured deviations of the thermal flow meter in the flow rate range from $0.5 \mathrm{ml} / \mathrm{h}$ to $2.0 \mathrm{ml} / \mathrm{h}$ for two different back pressures at a temperature of $22{ }^{\circ} \mathrm{C}$. The flow rates have been given an artificial off set in order to better visualize the results, for example the last 2 measurements are all for a flow rate of $2 \mathrm{ml} / \mathrm{h}$.

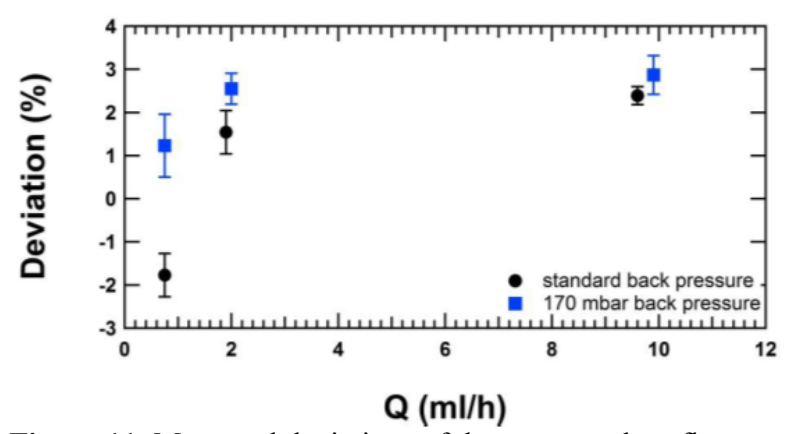

Figure 11. Measured deviations of the pressure drop flow meter in the flow rate range from $0.75 \mathrm{ml} / \mathrm{h}$ up to $10 \mathrm{ml} / \mathrm{h}$ for two different back pressures at a temperature of $22 \mathrm{C}$. The flow rates have been given an artificial off set in order to better visualize the results, for example the last 2 measurements are all for a flow rate of $10 \mathrm{ml} / \mathrm{h}$.

\subsection{Viscosity dependency}

The flow meters have been tested using 3 different liquids: water, water-glucose mixture with viscosities of 2 times and 4 times of water. The following flow rates 0.5 $\mathrm{mL} / \mathrm{h}, 2 \mathrm{~mL} / \mathrm{h}$ and $10 \mathrm{~mL} / \mathrm{h}$ are investigated.

The flow has been generated by means of a syringe pump, which is easy to handle with the different liquids and can be easily connected to the weighing system.

As expected, the Coriolis flow meter is not sensitive to any change in viscosity. However, we observe a decreasing flow rate with increasing viscosities and decreasing specific heat capacity of the liquids for the thermal flow meter. The change in the indications of the flow rates is probably not due to different viscosities, but results from the different specific heat capacities.

These measurements were not performed with the pressure drop flow meter as the manufacturer reminded that other liquids than ultrapure or deionized water could damage the flow meter.

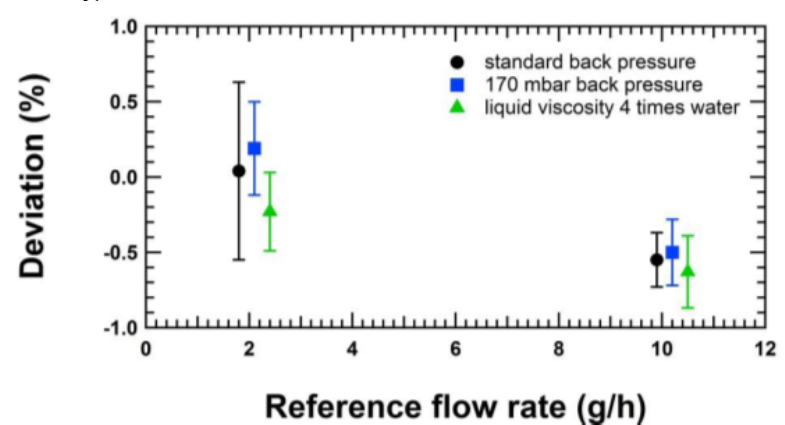

Figure 12. Measured deviations of the Coriolis flow meter in the flow rate range from $2.0 \mathrm{~g} / \mathrm{h}$ up to $10 \mathrm{~g} / \mathrm{h}$ using water and a water-glucose mixture with the viscosity of $4 \mathrm{mPa} . \mathrm{s}$ at a temperature of $22{ }^{\circ} \mathrm{C}$. The flow rates have been given an artificial off set in order to better visualize the results, for example the last 3 measurements are all for a flow rate of 10 $\mathrm{ml} / \mathrm{h}$.

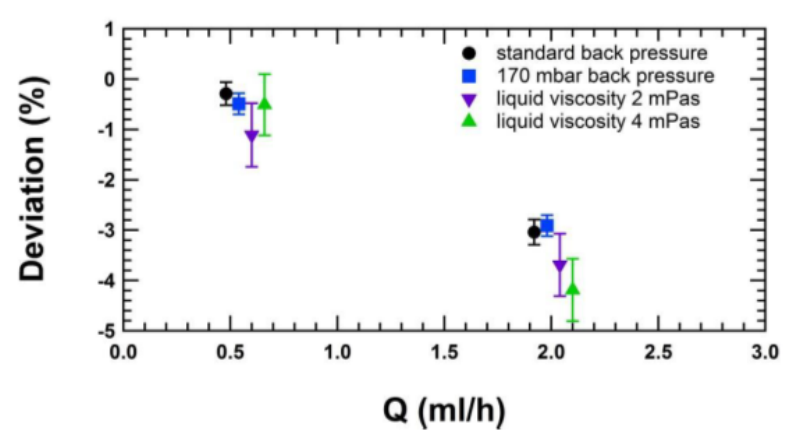

Figure 13. Measured deviations of the thermal flow meter in the flow rate range from $0.5 \mathrm{ml} / \mathrm{h}$ to $2.0 \mathrm{ml} / \mathrm{h}$ using water and water-glucose mixtures with the viscosity of $2 \mathrm{mPa}$.s and 4 $\mathrm{mPa}$.s at a temperature of $22^{\circ} \mathrm{C}$. The flow rates have been given an artificial off set in order to better visualize the results, for example the last 4 measurements are all for a flow rate of 2 $\mathrm{ml} / \mathrm{h}$.

\section{Drug delivery devices assessment}

Drug delivery devices or infusion instruments are widely used in the clinical environment. Their main function is to provide drug therapy, nutrition and hydration 
intravenously to patients. Drug delivery is used for almost all hospitalized patients and also for many in home care. In several international studies [5], it is stated that the dosage of infused pharmaceuticals is subject to uncertainties that may compromise the patient treatment. In infusion applications, the dosage is controlled by the flow rate of the infusion pump and a drug solution of known concentration.

Infusion devices must be reliable when used in drug delivery. The normal calibration procedure described in ISO 60601-2-24 [6] does not take into consideration the variations when these instruments are used in field applications, e.g. usage of accessories and varying operating conditions are omitted. Furthermore, not all buoyancy corrections are taken into account.

Consequently, calibrations at low flow rates may be subjected to significant uncertainties which can lead to undesired patient treatment.

For critical drug delivery it is important to have a constant and well-known infusion rate delivered by the complete infusion set-up (pump, tubing and accessories Figure 14). Therefore, in this workpackage various drug delivery devices and accessories were tested on their infusion accuracy, start-up delay, response time and dependency on the viscosity. Some results for a syringe pump can be found in Figure 15 and Figure 16.

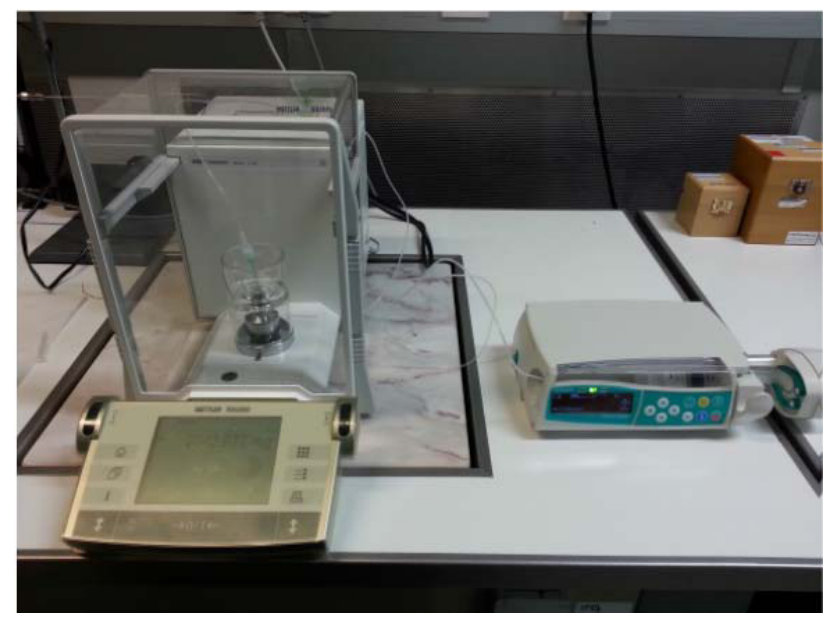

Figure 14. Gravimetric set-up for syringe pump calibration by gravimetric method.

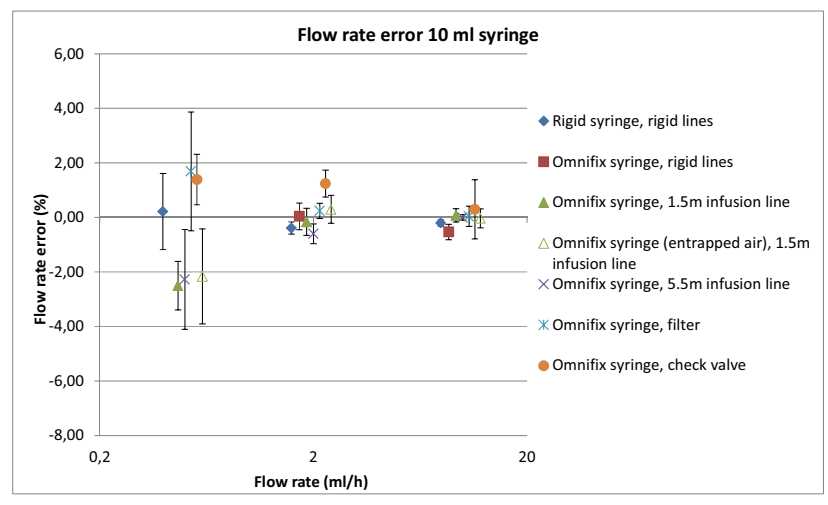

Figure 15. Relative flow rate error as function of the target flow rate and various accessories for a syringe volume of $10 \mathrm{ml}$.

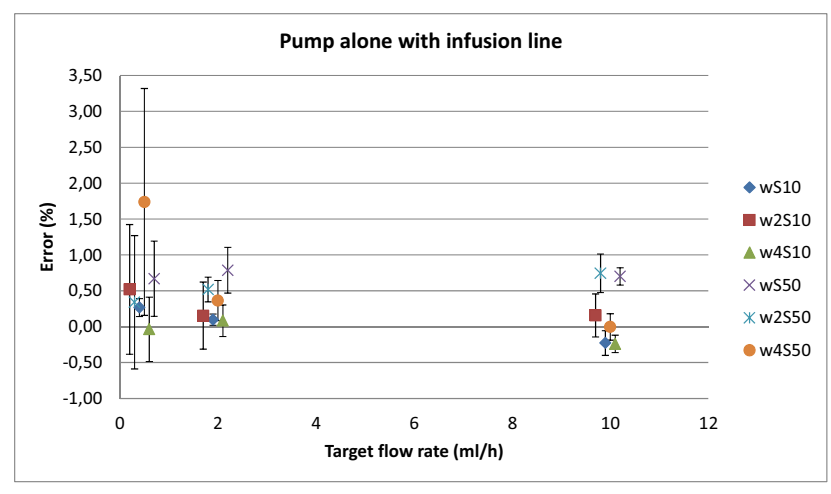

Figure 16. Relative flow rate error as function of the target flow rate and viscosity. wS10 corresponds to water using a $10 \mathrm{ml}$ syringe, w2S10 corresponds to the $2 \mathrm{mPa} \cdot \mathrm{s}$ solution using a 10 $\mathrm{ml}$ syringe and $\mathrm{w} 4 \mathrm{~S} 10$ corresponds to the $4 \mathrm{mPa} \cdot \mathrm{s}$ solution using a $10 \mathrm{ml}$ syringe, the same is valid for the $50 \mathrm{ml}$ syringe.

The results obtained in this study shows that the devices are sensible to variations in use, in particular at small flow rates and when using large syringes. However, in general the pump performs within its claimed accuracy specifications. In general, the lower the flow rate, the larger is the standard deviation of the results. More information can be found in [7].

\section{Information dissemination}

The technical work in this JRP addressed the need for insight into drug delivery systems, and with this knowledge it was the aim of this JRP to support reducing the number of adverse incidents involving drug delivery systems. The group of users of drug delivery systems is large and it consists of nurses, doctors, care providers and other medical personnel e.g. engineers.

To reach this audience and to create impact on a broad scale the following approach was followed:

- Short and easy to understand articles submitted for publication in the weekly/monthly magazines and emagazines for medical personnel. This will reach a broad audience.

- Scientific publications in high impact journals and for conferences in order to reach the specialists as well as to support those who seek a deeper understanding.

- A website and forum for open discussions at www.drugmetrology.com.

- Interactions with the stakeholder group to discuss and possibly steer the overall direction of the research.

- Input to existing and possibly to new standards.

A survey on best infusion practices was already undertaken and the results have been published as a best practice guide at the end of the project [8].

\section{Conclusions}

The calibration capabilities and the corresponding uncertainties of the primary standards of the NMIs involved in the JRP have been validated by means of the research inter-comparison for the flow rate range from 10 
$\mathrm{ml} / \mathrm{min}$ down to $2 \mu \mathrm{l} / \mathrm{min}$. Based on this achievement several NMIs have now submitted their Calibration Measurement Capabilities to the EURAMET Technical Committee for Flow for approval.

WP2 addressed the problem of flow meters dependency on several parameters. It has been shown that flow meters of Coriolis principle are generally the most accurate in the conditions tested (temperature, back-pressure, pulsation of flow, and viscosity of liquid). In general the impact of the viscosity, back pressure and temperature is not significant to the calibration uncertainty.

From the results obtained in WP3 it was verified that the studied drug delivery devices are sensible to variations in use, in particular at small flow rates and when using large syringes. Some work with a different brand of syringe pumps is still undergoing.

Several scientific papers and workshop participation have been done. At the end of the project a best practice guide for the use of drug delivery devices has been delivered to the medical community.

This JRP was carried out with funding by the European Union. The EMRP is jointly funded by the EMRP participating countries within EURAMET and the European Union.

\section{References}

1. P. Lucas et al., I, EU-funded research project $2012-$ 2015, partners CETIAT, CMI, DTI, METAS, IPQ, Tubitak, web site at drugmetrology.com.

2. H. Bissig et al., Primary Standards for Flow Rates from $100 \mathrm{nl} / \mathrm{min}$ to $1 \mathrm{ml} / \mathrm{min}$-Gravimetric Principle, J. of Biomed. Eng., (to be published)

3. EURAMET project 1291 - Comparison of primary standards for liquid micro flow rates, final report, (April 2015), available online at: http://www.euramet.org/Media/docs/projects/EURA MET-P1291_FLOW_Final_Report.pdf

4. H. Bissig et al., Flow meter assessment (D2.3.3, D2.3.6, D2.3.7), report published on the website www.drugmetrology.com (May 2015).

5. C. Melvad, U. Kruhne, J. Frederlkesen, Design considerations and initial validation of a liquid microflow calibration setup using parallel operated syringe pumps, IOP Publishing, Measurement Science and Technology (2010)

6. IEC, IEC 60601-2-24 (1998). Medical electrical equipment - Part 2-24: Particular requirements for the safety of infusion pumps and controllers, Switzerland (1998)

7. E. Batista et al., Assessment of drug delivery devices, accepted for publication in Journal of Biomedical Engineering (2015)

8. P. Lucas et al., Best Practice Guide, report published on the website www.drugmetrology .com (May 2015). 